\title{
A comparison between the effects of hypophysectomy and adrenalectomy on the gastric mucosa of the rat
}

\author{
GERARD P. CREAN ${ }^{1}$ \\ From the Medical Research Council Clinical Endocrinology Research Unit, \\ University of Edinburgh
}

It is shown in the previous paper that there was a marked reduction in the volume (mass) of the mucosa and in the total parietal cell population of the stomach after hypophysectomy in the rat (Crean, 1968); however, it remained to be established whether these effects were due to deficiency of the hormones of the pituitary itself, or to secondary deficiency of the hormones of one of its target organs.

A review of the literature (Crean, 1963) suggested that the adrenal cortex is the only target endocrine gland capable of exerting any marked influence on the structural integrity of the gastric mucosa, the thyroid and the gonads appearing to exert no, or little, influence in this respect. Thus adrenalectomy causes a marked reduction in the weight of the gastric and intestinal mucosa in cats (Haeger, Jacobsohn, and Kahlson, 1953) and produces profound involution of the zymogenic cells in rats (Baker and Bridgman, 1954), although it does not appear to affect either the cytological structure or the total number of parietal cells in the stomach in this species (Baker and Bridgman, 1954; Bralow, Komarov, and Shay, 1964); however, the observations of Bralow et al., concerning the effects of adrenalectomy on the total parietal cell population, were limited to a small number of animals, and the authors did not comment on the effects of the procedure on any other parameter of the growth of the gastric mucosa.

In the present experiment the effects of hypophysectomy and total adrenalectomy on the stomach are compared in rats, as a further step in the investigation of the mechanisms by which the endocrine system may influence the stomach. Somatic growth ceases after hypophysectomy in the rat and in order that this effect could be taken into account in the assessment of the results the experiment included a group of intact animals whose growth was inhibited by underfeeding (Crean, 1968). 'Present address: The Gastrointestinal Centre, Southern General Hospital, Glasgow, S.W.1.

\author{
MATERIALS AND METHODS
}

A homogenous population of 32 young male rats was selected from a single generation in the closed colony of the Wistar strain maintained in the Clinical Endocrinology Research Unit. The animals were kept eight to a cage until their mean body weight reached $120 \mathrm{~g}$, when the individual rats were allocated in random order to one or other of the following treatment groups (numbers of animals in parentheses).

GROUP 1 Hypophysectomy, to be fed ad libitum (10)

GROUP 2 Sham hypophysectomy to be fed ad libitum (6)

GROUP 3 Sham hypophysectomy to be underfed (6)

GROUP 4 Bilateral adrenalectomy to be fed ad libitum (10)

Larger numbers were deliberately allocated to groups 1 and 4 than to groups 2 and 3, in order to allow for an anticipated mortality from the major surgical procedures; in the event, seven of the hypophysectomized and eight of the adrenalectomized animals survived for the duration of the experiment. All the operations were carried out on the same day; hypophysectomy was performed by the parapharyngeal route and bilateral adrenalectomy by a midline dorsal approach. By 'sham hypophysectomy' is meant an operation which resembles exactly that performed when the pituitary is to be removed up to and including the point when a burr hole is made in the base of the skull; the pituitary is left intact in the case of the sham procedure whereas it is removed by suction when an actual hypophysectomy is to be performed. At adrenalectomy the perinephric fat was cleared as completely as possible so as to remove any accessory adrenal tissue present.

The four groups were caged separately from the day of operation; the animals were weighed daily, and they had free access to a solution containing $5 \%$ glucose, $1 \%$ sodium chloride, and vitamin supplements for their fluid requirements. A diet consisting of the standard rat cake used in this Unit pulped to softness with brown bread, fresh milk, and glucose was used throughout the experiment; while groups 1,2 and 4 were provided 
with this diet in excess of their needs, the amount of food allowed to group 3 was restricted on a day-to-day basis so as to maintain their mean body weight at the same level as that of group 1. All the animals were killed on the 22nd day after operation. At necropsy it was confirmed that the pituitary was intact in groups 2 and 3, and that the pituitary and both adrenals had been completely removed in groups 1 and 4 respectively; no accessory adrenal tissue was found in the animals in group 4. The paired testes were removed from all animals, and the paired adrenals from groups 1, 2, and 3; these organs were stripped of their attached blood supply and fat, placed immediately in $10 \%$ formol-saline, and weighed subsequently on the same day after being dried by swabbing. The mean weights of these organs in the four groups are given in the Table of results; the data confirm that the pituitary had been completely removed in the animals in group 1, and they will not be considered further except to observe that the weight of the adrenals and testes were reduced by underfeeding.

The stomach was removed as quickly as possible after death and processed as previously described; the weight of the whole stomach was noted, and the surface area, height and volume of the fundic mucosa, and the total parietal cell population of each stomach were estimated, mucosal volume being calculated as the product of the surface area and the mean height of the fundic mucosa in each animal (Crean, 1968). It should be emphasized that all histological observations were made in ignorance of the identity of the tissues under consideration.
RESULTS

The results and the summaries of the $t$ tests for the comparisons between the means of the observations in the four groups are set out in the Table; the mean body weight curves of the four groups are illustrated in Fig. 1, and the values obtained for the parietal cell population in individual rats are plotted against body weight in Figure 2.

INITIAL BODY WEIGHT AND THE GROWTH CURVES OF THE FOUR GROUPS The four groups differed considerably with respect to initial body weight (ie the weight recorded on the day the operations were carried out) due largely to the fact that the mean body weight of group 3 was considerably less than that of the other three groups. These were the animals allowed to feed ad libitum during the course of the experiment and it is extremely unlikely that their smaller initial size exerted any important influence on the results obtained; their subsequent growth rate was the same as that of intact rats of the same age in the colony so that for practical purposes they may be regarded as normal animals (Fig. 1). Although the mean body weight curve of the underfed animals was persistently maintained at a higher level than that of the hypophysectomized group, the

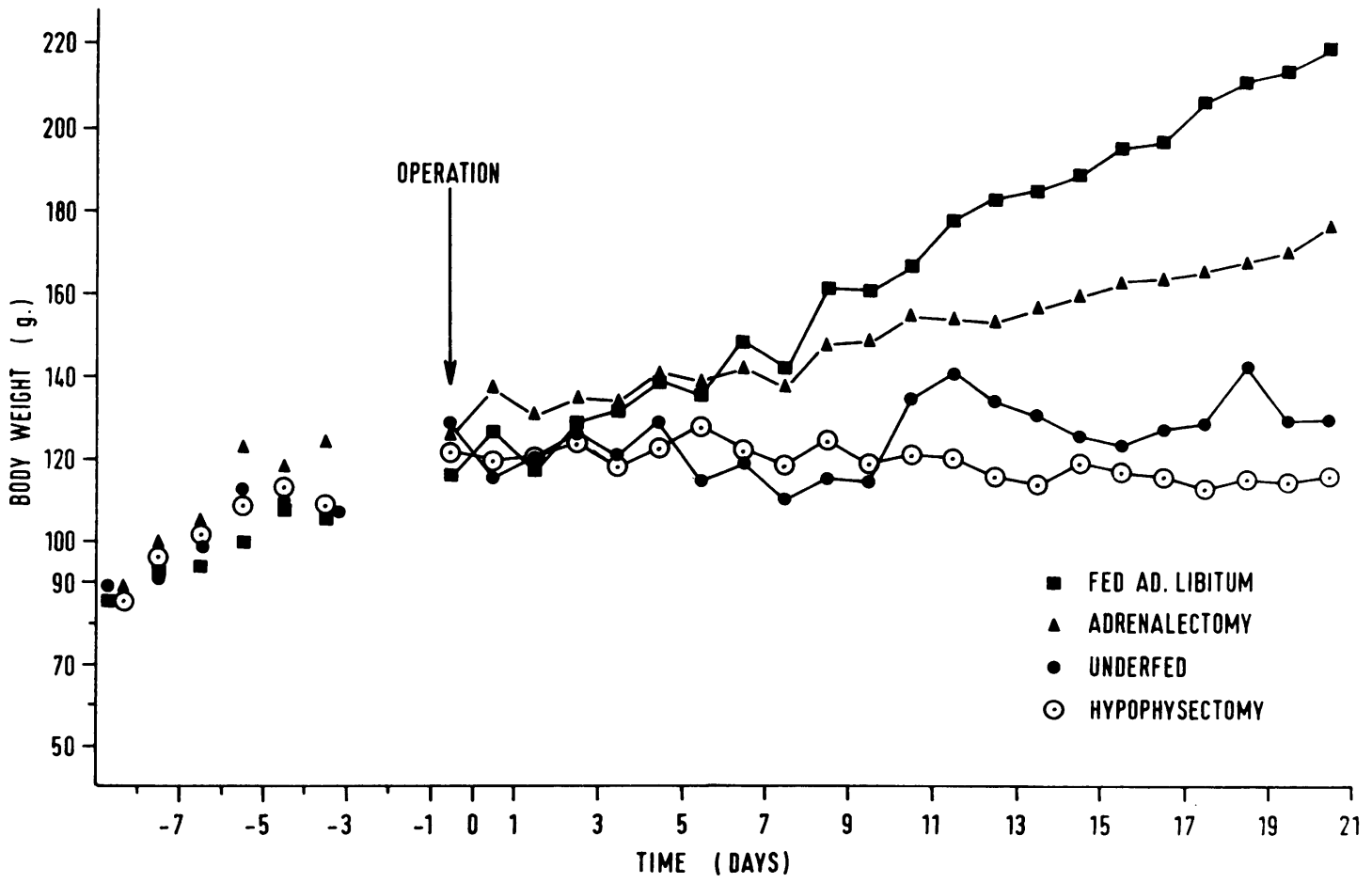

FIG. 1. The mean body weight curves of the four groups during the course of the experiment; the day of operation is indicated by the arrow. 
TABLE I

RESULTS IN FOUR GROUPS OF ANIMALS

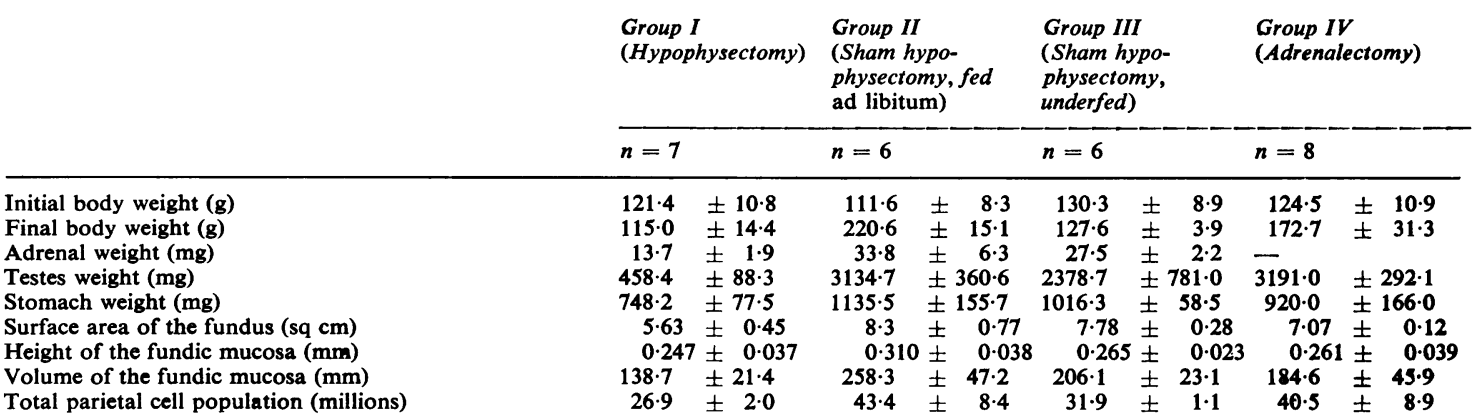

TABLE Ia

SUMMARY OF $\mathrm{t}$ TESTS FOR COMPARISONS BETWEEN MEANS

\begin{tabular}{|c|c|c|c|c|c|c|c|c|}
\hline $\begin{array}{l}\text { Initial } \\
\text { Body } \\
\text { Weight } \\
(\mathrm{g})\end{array}$ & $\begin{array}{l}\text { Final } \\
\text { Body } \\
\text { Weight } \\
(g)\end{array}$ & $\begin{array}{l}\text { Adrenal } \\
\text { Weight } \\
(g)\end{array}$ & $\begin{array}{l}\text { Testes } \\
\text { Weight } \\
(\mathrm{g})\end{array}$ & $\begin{array}{l}\text { Stomach } \\
\text { Weight } \\
(\mathrm{g})\end{array}$ & $\begin{array}{c}\text { Surface } \\
\text { Area of } \\
\text { Fundus } \\
(s q \mathrm{~cm})\end{array}$ & $\begin{array}{l}\text { Mucosal } \\
\text { Height } \\
(\mathrm{mm})\end{array}$ & $\begin{array}{l}\text { Mucosal } \\
\text { Volume } \\
\left(\mathrm{mm}^{3}\right)\end{array}$ & $\begin{array}{l}\text { Total } \\
\text { Parietal } \\
\text { Cell } \\
\text { Population } \\
\text { (m) }\end{array}$ \\
\hline
\end{tabular}

\begin{tabular}{|c|c|c|c|c|c|c|c|c|c|c|}
\hline $\begin{array}{l}\text { Hypophysectomy } \\
\text { vs }\end{array}$ & Value for $t$ & $1 \cdot 7$ & $12 \cdot 8$ & $7 \cdot 47$ & $17 \cdot 96$ & $5 \cdot 5$ & $7 \cdot 5$ & $3 \cdot 01$ & $5 \cdot 7$ & $5 \cdot 7$ \\
\hline $\begin{array}{l}\text { (2) } \\
\text { fed ad libitum } \\
D \text { of } F=11\end{array}$ & $\mathbf{P}$ & $<0.2$ & $<0.001$ & $<0.001$ & $<0.001$ & $<0.001$ & $<0.001$ & $<0.02$ & $<0.001$ & $<0.001$ \\
\hline $\begin{array}{l}\text { (1) } \\
\text { Hypophysectomy } \\
\text { vs }\end{array}$ & Value for $t$ & $1 \cdot 7$ & $2 \cdot 2$ & $9 \cdot 47$ & $6 \cdot 01$ & $7 \cdot 1$ & $12 \cdot 3$ & $1 \cdot 07$ & $5 \cdot 4$ & $4 \cdot 3$ \\
\hline $\begin{array}{l}(3) \\
\text { underfed } \\
D \text { of } F=11\end{array}$ & $\mathbf{P}$ & $<0.2$ & $<0.05$ & $<0.001$ & $<0.001$ & $<0.001$ & $<0.001$ & $<0.4$ & $<0.001$ & $<0.005$ \\
\hline $\begin{array}{l}\text { (1) } \\
\text { Hypophyseetomy } \\
\text { vs }\end{array}$ & Value for $t$ & 0.5 & $4 \cdot 68$ & 一 & $25 \cdot 2$ & $2 \cdot 6$ & $3 \cdot 2$ & $0 \cdot 71$ & $2 \cdot 5$ & $4 \cdot 2$ \\
\hline $\begin{array}{l}(4) \\
\text { adrenalectomy } \\
D \text { of } F=13\end{array}$ & $\mathbf{P}$ & $<0.7$ & $<0.001$ & - & $<0.001$ & $<0.025$ & $<0.01$ & $<0.5$ & $<0.05$ & $<0.005$ \\
\hline $\begin{array}{l}\text { (2) } \\
\text { Fed ad libitum } \\
\text { vs }\end{array}$ & Value for $t$ & $3 \cdot 8$ & $2 \cdot 2$ & $2 \cdot 14$ & $2 \cdot 18$ & $1 \cdot 7$ & $1 \cdot 6$ & $2 \cdot 46$ & $2 \cdot 4$ & $3 \cdot 2$ \\
\hline $\begin{array}{l}\text { underfed } \\
D \text { of } F=10\end{array}$ & $\mathbf{P}$ & $<0.005$ & $<0.001$ & $<0.1$ & $<0 \cdot 1$ & $<0.2$ & $<0.2$ & $<0.05$ & $<0.05$ & $<0.01$ \\
\hline $\begin{array}{l}\text { (4) } \\
\text { Adrenalectomy } \\
\text { vs }\end{array}$ & Value for $t$ & $2 \cdot 3$ & $3 \cdot 77$ & - & 0.3 & $2 \cdot 5$ & $2 \cdot 4$ & $2 \cdot 34$ & 2.9 & 0.5 \\
\hline $\begin{array}{l}\text { (2) } \\
\text { fed ad libitum } \\
D \text { of } F=12\end{array}$ & $\mathbf{P}$ & $<0.05$ & $<0.005$ & - & $<0.8$ & $<0.05$ & $<0.05$ & $<0.05$ & $<0.02$ & $<0.7$ \\
\hline $\begin{array}{l}\text { (4) } \\
\text { Adrenalectomy } \\
\text { vs }\end{array}$ & Value for $t$ & $1 \cdot 2$ & $3 \cdot 70$ & 一 & $2 \cdot 43$ & $1 \cdot 5$ & $1 \cdot 6$ & $0 \cdot 24$ & $1 \cdot 1$ & $2 \cdot 7$ \\
\hline $\begin{array}{l}\text { underfed } \\
D \text { of } F=12\end{array}$ & $\mathbf{P}$ & $<0.3$ & $<0.005$ & 一 & $<0.05$ & $<0.2$ & $<0.2$ & $<0.9$ & $<0.3$ & $<0.02$ \\
\hline
\end{tabular}

${ }^{1}$ Mean and standard deviation of each observation 


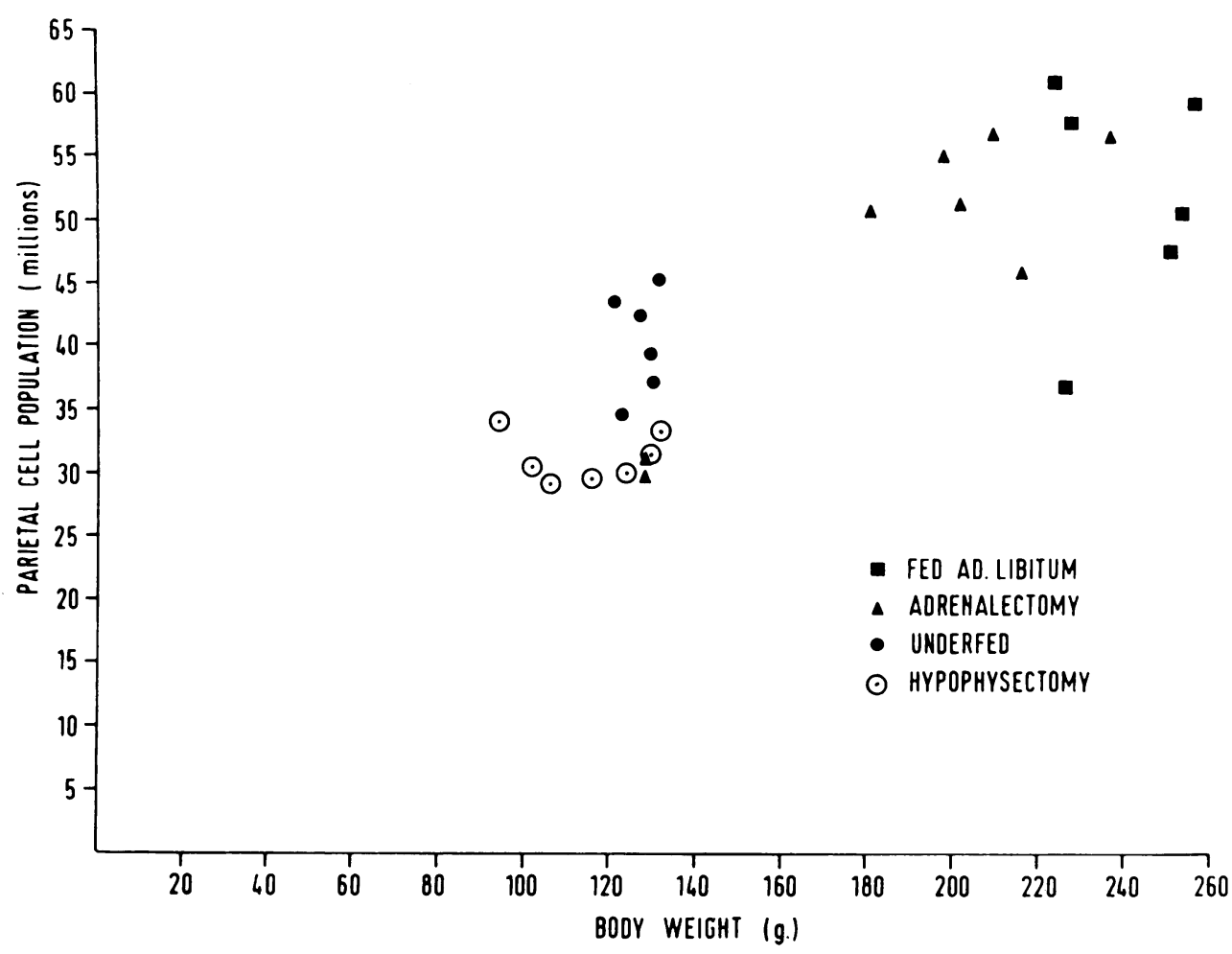

FIG. 2. The parietal cell population in individual rats plotted against body weight; the animals in each group are represented by different symbols.

discrepancy was relatively small and there was only a slight difference between the two groups with respect to final body weight $(P<0.05)$. As expected, the growth curve of the adrenalectomized animals was retarded (Reichlin and Brown, 1960; Grunt, 1964) and the mean final body weight of this group was significantly smaller $(P<0.005)$ than that of group 2 although it was greater than those of groups 3 and 1.

EFFECTS OF HYPOPHYSECTOMY AND UNDERFEEDING ON THE GASTRIC MUCOSA Hypophysectomy and underfeeding both exerted considerable effects on the stomach. Thus there were highly significant differences $(\mathrm{P}<0.001)$ between the fed ad libitum group (group 2) and the hypophysectomized animals (group 1) with respect to all the observations made on the stomach except for mucosal height $(P<0.02)$, and there were significant differences between the group fed ad libitum and the underfed animals (group 3) with respect to surface area $(P<0.01)$, mucosal volume $(P<0.05)$, and total parietal cell population $(P<0.005)$. However, the effects of hypophysectomy (group 1) were considerably greater than the effects of underfeeding (group 3) so that there were highly significant differences $(\mathrm{P}<0.005-<0.001)$ between these two groups with respect to all the gastric observations except for mucosal height $(P<0.4)$; the effect of hypophysectomy on the stomach was so much greater than the effect of underfeeding that the differences between the two groups in this respect cannot be ascribed to the relatively slight differences in their respective growth curves but may be attributed instead to a specific effect of hypophysectomy on the stomach.

EFFECTS OF ADRENALECTOMY ON THE GASTRIC MUCOSA Bilateral adrenalectomy had little effect on the stomach; thus there were no significant differences between the adrenalectomized group (group 4) and the group fed ad libitum (group 2) with respect to the volume of the fundic mucosa or the total parietal cell population, although the mean values for stomach weight and surface area were significantly less $(P<0.05)$ in the adrenalectomized animals. However, these differences can be attributed almost entirely to the low values obtained for both observations in two animals which sustained the operation 
poorly; these animals developed severe diarrhoea and lost weight markedly during the last 10 days of the experiment. The rats in question are represented by the two lowest values for parietal cell population plotted for the adrenalectomized animals in Fig. 2; the low values obtained for surface area in these two animals wholly account for their relatively small parietal cell populations. The data show that the effects of adrenalectomy on the stomach are negligible in comparison with the effects of hypophysectomy, and there were highly significant differences between the two groups with respect to stomach weight $(P<0.05)$, surface area $(P<0.001)$, mucosal volume $(\mathrm{P}<0.001)$, and parietal cell population $(\mathrm{P}<0.001)$.

\section{DISCUSSION}

The results of this experiment confirm that the effect of hypophysectomy on the gastric mucosa of the rat is not due simply to the inhibition of somatic growth which follows pituitary deprivation in this species (Crean, 1968) and they establish that the effect is not due to secondary deficiency of the adrenocortical hormones either. Since the values obtained for the various gastric parameters must represent the extent to which the gastric mucosa had developed in an individual animal at the time it was killed, the differences observed between the four experimental groups may be attributed to differences between them with respect to the growth of the gastric mucosa before death. On this argument hypophysectomy imposed a severe limitation of the growth of the stomach, underfeeding imposed a less marked limitation whereas adrenalectomy exerted no, or little effect in this respect.

The results obtained by Bralow et al. (1964) support the conclusion that the growth of the gastric mucosa is not influenced by adrenalectomy in the rat; these authors found no alteration in the parietal cell population of four rats after adrenalectomy despite the fact that gastric secretion was markedly reduced. Although the overall growth of the gastric mucosa is not affected, it appears that adrenalectomy causes a marked increase in the mitotic activity both of the surface epithelial cells and of the mucous neck cells of the stomach in the rat (Clark and Baker, 1962); presumably this increased mitotic activity must be balanced in some way by increased cell loss since there was no evidence in the present experiments of any alteration in the actual mass of the gastric mucosa.

The results obtained in this experiment clearly indicate that the influence of the pituitary on the growth of the gastric mucosa is not mediated by the adrenal cortex at least in the rat, and as noted earlier it appears unlikely that the effect is mediated by any of the other target endocrine organs either (see Crean, 1963). A more satisfactory method of investigating the mechanisms by which the pituitary exerts its influence on the stomach would be to examine the effects of the individual pituitary hormones in restoring the growth of the gastric mucosa after hypophysectomy; such an experiment has been carried out in this laboratory and the results will be reported in a subsequent paper.

\section{SUMMARY}

The effects of hypophysectomy and total adrenalectomy on the weight of the whole stomach, on the surface area and volume of the fundic mucosa, and the total parietal cell population were compared in rats. Hypophysectomy markedly reduced the values obtained for all these observations. It was confirmed that this effect must be due to a specific effect of pituitary deprivation on the stomach, and that it could not be accounted for simply by the inhibition of somatic growth which follows pituitary deprivation in this species. Total adrenalectomy exerted no significant effects on the gastric mucosa.

The results indicate that the influence of the pituitary on the growth of the gastric mucosa is not mediated via the adrenal cortex.

I wish to thank Dr J. A. Loraine, Dr Talib Astrabadi and Dr K. E. Kirkham for their advice and help, and Mr John Mitchell, Miss Alice Lawrie and Mr R. D. E. Rumsey for expert technical assistance. The investigations were undertaken during the tenure of a personal grant from the Medical Research Council.

\section{REFERENCES}

Baker, B. L., and Bridgman, R. M. (1954). The histology of the gastrointestinal mucos i (rat) after adrenalectomy or administration of adrenocortical hormones. Amer. J. Anat., 94, 363-397.

Bralow, S. P., Komarov, S. A., and Shay, H. (1964). Effect of total adrenalectomy on gastric secretion in chronic gastric fistula rats. Amer. J. Physiol., 206, 1309-1314.

Clark, R. H., and Baker, B. L. (1962). Effect of adrenalectomy on mitotic proliferation of gastric epithelium. Proc. Soc. exp. Biol. (N.Y.), 111, 311-315.

Crean, G. P. (1963). The endocrine system and the stomach. Vitam. and Horm., 21, 215-280.

(1968). Effect of hypophysectomy on the gastric mucosa of the rat. Gut, 9, 332-342.

Grunt, J. A. (1964). Effects of adrenalectomy and gonadectomy on growth and development in the rat. Endocrinology, 75, 446-451.

Haeger, K., Jacobsohn, D., and Kahlson, G. (1953). Atrophy of the gastrointestinal mucosa following hypophysectomy or adrenalectomy. Acta physiol. scand. 30, suppl. 111, 161-169.

Reichlin, S., and Brown, J. G. (1960). Growth in adrenalectomised rats. Amer. J. Physiol., 199, 217-220. 